\title{
THE MAN AND THE MOUNTAIN: DOUGLAS ON RELIGIOUS FREEDOM*
}

\author{
DAVID W. LOUISELL $\dagger$ \\ "... [T] he kingdom of heaven suffereth violence, \\ and the violent bear it away."1
}

What kind of mind and man came to the United States Supreme Court a quarter of a century ago to wrestle with perhaps the most fundamental, difficult and pervasive complex of problems ever to face that tribunal? For the problems of God and Caesar, which at root are the ultimate ones of human liberty itself, inflame the passions of man and, especially in America's pluralistic environment, tax his intellect, as few problems can. That it was a mind gifted by nature to the point of genius, honed to the precisional fineness of the excellent corporate lawyer, disciplined by intense struggle and labor, informed by exacting and dedicated public service, and possessed of a restlessness intolerant of all but the truth or its persistent quest, I submit is documented in this issue by my colleague. ${ }^{2}$ That this was a person of vital and vibrant religious feeling and conviction - one who with William James had concluded that "we and God have business with each other"3 - is apparent from his own largely autobiographical writings. To read $O f M e n$ and Mountains $^{4}$ is to be reminded of some of the spiritual poetry in Tolstoi or Bernanos or Merton.

First, there is Faith - the kind that moves the mountains of which Douglas writes.

One cannot reach the desolate crags that look down on eternal glaciers without deep and strange spiritual experiences. If he ever was a doubter,

*Discussion of a man's views on religious freedom, more so than most studies, naturally puts the subject in the frame of world events. When Justice Douglas took his oath on April 17, 1939, 306 U.S. iii, Hitler and Mussolini were dominant. The dissolution of the British Empire, then only begun, is now all but complete. The war we fought to anchor us to security's rock has left us instead loose on a precipice. A fourth President of the United States recently has been assassinated. And despite an affluence that makes it hard for us to convince our children that there ever was a depression, perhaps a fifth of our people still live so far outside the mainstream of American life that it may be said of them, they know "poverty in the Middle East meaning of the word." Douglas, Strange Lands and Friendly People (Dedication) (1951).

I thank my colleague Albert Ehrenzweig for reading the manuscript and for suggestions.

†Elizabeth Josselyn Boalt Professor of Law, University of California, Berkeley.

1. Matthew $11: 12$ (Douay).

2. Jennings, Mr. Justice Donglas: His Infuence Upon Corporate and Securities Regulation, 73 Y $\mathrm{ALE}$ L.J. 920 (1964). As to the intense labor, witness, e.g., simultaneous practice and teaching at Columbia. Id. at 922.

3. Jaxies, The Varieties of Religious Experientce 516 (Longmans, Green \& Co. ed.) (1958)

4. Douglas, Of Men and Mountains (1950). 
he will, I think, come down a believer. He will have faith. He will know there is a Creator, a Supreme Being, a God, a Jehovah. He will know it because otherwise the mind cannot comprehend how life could have been created out of the inert matter. When he sees the stuff that was the beginning of life, he will know that it took an omniscient One to sculpture man; to fashion one who can laugh, and cry, and love; to mold out of rock a soul that can aspire to the stars and a heart that can sacrifice all for an idea or a loved one. ${ }^{5}$

It is faith from his father - a missionary of the Presbyterian church:

I stood in the silence of the gathering night, [coming down Kloochman] charting my course by it. Then the words my father had spoken came back: "If I die it will be glory. If I live, it will be grace."

That was his evening star - a faith in a power greater than man. That was the faith of our fathers - a belief in a God who controlled man and the universe. It manifested itself in different ways to different people. It was written by scholars and learned men into dozens of different creeds. There were sects and schisms and religious disputes. But riding high above all such secular controversies was the faith in One who was the Creator, the Giver of Life, the Omnipotent. ${ }^{6}$

Nor is Douglas' faith that of one who sees only an aloof God, majestic but unapproachable, indifferent to the trials and tribulations of petty man. It is a faith that was born and bred to prayer.

But before many months I relearned to walk, and the frailty which the disease [infantile paralysis] had caused seemed to pass. Someone said that the salt water and massages had effected wonders. Mother was silent awhile and then said, "So did my prayers."7

And it is faith that reflects this heritage. To acknowledge prayer embarrasses the son no more than the mother. Remembering a $1913 \mathrm{climb}$ of Mt. Kloochman, Douglas writes :

All was silent. A pebble fell from the ledge on which I squeezed. I counted seconds before it hit 600 feet below with a faint, faraway tinkling sound.

5. Id. at 308 .

6. Id. at 329. In Douglas, Russtan Journey 203 (1956) he stated:

That morning [at Baku] religion seemed to me to be on its way out in Russia. As I watched the handful of poor people kiss the Bible held by the priest, memories of my Father and Mother came back to me. Father had given his life to the Presbyterian Church. Mother was his faithful co-worker. ... And so at the end of the service I bought two candles from an aged, shawled lady dressed in black and lighted them with a prayer for my parents.

But as the days passed and he saw more churches, his opinion that religion in Russia was dying changed.

I became convinced that religion in Russia will last as long as the Russian people; that it is as sturdy and enduring as the shawled women and booted men who kneel before the cross.

Ibid. Unlike some other visitors to Russia, his sense of truth causes him to say:

In all of Russia the campaign against religion is incessant. It starts in the nursery and kindergarten that are found in every town and factory and on every farm. Id. at 201.

7. Douglas, op. cit. supra note 4 , at $31-32$. 
Would Doug [his mountain-climbing companion] drop through the same space? Would I follow? When you fall 600 feet do you die before you hit the bottom? Closing my eyes, I asked God to help Doug up the wall. ${ }^{8}$ * * *

... On these dark walls in 1913 I had first communed with God. Here I had felt the presence of a Mighty Force, infinitely beyond man. Here I had known the strength of unseen hands helping me along ledges. ${ }^{9}$

But for Douglas religion is more than prayer. It is an understanding of the world, an orientation to reality, the basis of a personal philosophy, a way of life.

There are other ways too in which mountains have spiritual values. When man ventures into the wilderness, climbs the ridges, and sleeps in the forest, he comes in close communion with his Creator. When man pits himself against the mountain, he taps inner springs of his strength. He comes to know himself. $\mathrm{He}$ becomes meek and humble before the Lord that made heaven and earth. For he realizes how small a part of the universe he actually is, how great are the forces that oppose him. ${ }^{10}$

It is easy to see the delicate handiwork of the Creator in any meadow. But perhaps it takes these startling views [Mount Rainier in sight] to remind us of his omnipotence. Perhaps it takes such a view to make us realize that vain, cocky, aggressive, selfish man never conquers the mountains in spite of all his boasting and bustling and exertion. $\mathrm{He}$ conquers only himself. ${ }^{11}$

Most eloquently, Douglas sees religion as the poetry of life.

I never see the bitterroot blooming among the sage without feeling that I should take off my hat and stand in adoration at the wondrous skill of the Creator. I'll always remember the words of the artist who said, "I have grown to feel that there is nothing more amazing about a personal God than there is about the blossoming of the gorgeous little bitterroot."12

$$
\text { * * * }
$$

As I mushed along in the fluffy snow, I sensed the silence and solitude of the mountains in wintertime. There is no movement, no ripple of life anywhere. On such a morning in a high valley under deep snow man comes closer to God. This is the solitude of all time. Here man has left behind the noise and whir of life. He walks as if he were the first arrival. He finds the inner harmony that comes from communion with the heavens. He can draw strength from the austere, majestic beauty around him. ${ }^{13}$

There is a universal quality about bread, whatever may be its color or ingredients. Like air and water and sunshine it is a part of the life of all peoples. Like the family, it is part of our traditions. Gandhi once said, "God himself dare not appear to a hungry man except in the form
8. Id. at 318 .
9. Id. at 326 .
10. Id. at 18 .
11. Id. at 69.
12. Id. at 50 .
13. Id. at 278 . 
of bread.” Ben Hur Lampman once printed a verse written by an anonymous author:

Be gentle when you touch bread

Let it not lie uncared for, unwanted -

Too often bread is taken for granted.

There is such beauty in bread;

Beauty of sun and soil;

Beauty of patient toil;

Wind and rain have caressed it,

Christ often blessed it -

Be gentle when you touch bread. ${ }^{14}$

But Douglas' religion was not sentimentality, like so much that passes as religion today. It reflected what was, perhaps, Protestantism's most basic ethic of duty and individual accountability. As the Justice later wrote, dissenting in the "Blue Law" cases, "The Puritan influence helped shape our constitutional law and our common law as Dean Pound has said: The Puritan 'put individual conscience and individual judgment in the first place." "15 And Douglas' religion was concerned with the eschatological.

Man stands here [on Old Snowy] as I imagine he stands on Judgment Day - naked and alone, judged by the harmony of his soul, by his spiritual strength, by the purity of his heart. ${ }^{16}$

Dollars, guns, and all the wondrous products of science and the machine will not be enough: "This night thy soul shall be required of thee."17

Lastly, it should be noted that Douglas is a man not only of religious but of specifically Christian commitment. For example, in Strange Lands and Friendly People ${ }^{18}$ we observe his sense of longed-for encounter and communion with the fact and person of Christ - the quintessence of the Christian ethos.

We first saw the Sea of Galilee from a distance. . . The gravelly shores were covered with smooth pebbles. Many were colored - some flat, some round. They were the pebbles that were here when Christ walked these shores. I pocketed a few for a Sunday-school class back home. ${ }^{10}$

In village after village I saw the same sight; and as I went among these huts I got a new understanding of Christ at work in this area. I realized for the first time what Christ the Healer meant. To rise from any sickbed is a miracle. To rise from a sick bed surrounded by the squalor and stench of the Middle East without the aid of drugs or science is superhuman. I appreciated for the first time what hold Christ must have had on the ordinary people of this area. These disease-ridden folks had no doctors, no medicines, no hospitals; but He knew how to cure them. They saw Him make the afflicted whole with a word; and so they worshipped him

\footnotetext{
14. Id. at 257.

15. McGowan v. Maryland, 366 U.S. 420,563 (1961) (dissenting opinion).

16. Douglas, op. cit. supra note 4 , at 212 .

17. Id. at 329 .

18. Douglas, Strange Lands and Friendly People (1951).

19. Id. at 220 .
} 
and flocked in multitudes after Him. His deeds were the talk of the nation. One day the host that followed him was so great they had to let a sick man down through the roof because the doors were blocked. At Galilee the audience was so large $\mathrm{He}$ had to preach from a boat pushed out from the shore. It was Jesus the Healer whom they adored. No wonder there was a great commotion in a city when the word was passed, "They say that Jesus of Nazareth is come." No wonder the ecclesiastical powers of that day trembled at the thought of Christ's great popularity. By their standards a man who had such a hold on people was a dangerous man, a subversive influence. ${ }^{20}$

How has such a mind and man tackled the perennial and universal problems of God and Caesar in America today? One would expect that his starting point would be fidelity to religious freedom in its furthest reaches. For one who has seen America from its mountaintops and there breathed its purest air, would know that its loftiest spiritual ideal is freedom - and that freedom without freedom of religion is self-contradiction. He would know that as Judge he must be on constant alert lest the unconscious surreptitiously translate his own convictions into a mandate for others, to the ruin of freedom. For as Judge, duty may compel one to permit what he detests and to abjure what he loves. ${ }^{21}$ It is therefore consistent to observe Douglas, relatively early in his judicial career, in Murdock v. Pennsylvania, ${ }^{22}$ writing for the Court a decision which invalidated a municipal license tax imposed on religious colporteurs as a condition of their activities. Proclaiming the preferred position of freedom of religion, he cast aside the argument that the ordinance was constitutional because nondiscriminatory. "A license tax certainly does not acquire constitutional validity because it classifies the privileges protected by the First Amendment along with the wares and merchandise of hucksters and peddlers and treats them all alike."23

20. Id. at 232-33. In the Foreword to his An Alaranac of LIberty vi (1954) Justice Douglas says :

There could be as many Almanacs of Liberty as there are philosophies and points of view. ... My Almanac is concerned with the Sermon on the Mount, the United Nations, workmen's compensation, social security, as well as with habeas corpus and the Fifth Amendment.

Justice Douglas latest book, Mr. Lincoln AND THE Negroes (1963) focuses on Lincoln as a man of religion (although of no denomination).

21. Cf., Calamandrei, Procedure and Democracy 37-38 (1956):

The heroism of the judge can be measured by his degree of success in escaping from the prison of his private life; in spite of an inadequate salary that condemns his family to poverty he must protect the unlimited riches of others without envy and according to justice; even when his father's heart may urgently call him to the bedside of an ailing son, he must remain in the courtroom to listen to the prolix arguments of attorneys; and in a trial for legal separation he must, if justice requires it, be ready to decide against the husband even if in his own marital life he has been unhappy but blameless.

22. 319 U.S. 105 (1943). See also Jones v. Opelika, 316 U.S. 584, 600, 611' (1942) (Douglas, J., joining in dissenting opinion of Stone, C.J. and concurring in dissenting opinion of Murphy, J.), judgment vacated and state courts reversed, 319 U.S. 103 (1943).

23. 319 U.S. at 115. 
On the same decision day, Martin $v$. Struthers ${ }^{24}$ held invalid, as applied to a person distributing religious advertisements, a municipal ordinance forbidding anyone to summon residents to the door to distribute circulars. Justice Douglas consistently joined in Justice Murphy's concurring opinion: "I believe that nothing enjoys a higher estate in our society than the right given by the First and Fourteenth Amendments freely to practice and proclaim one's religious convictions." ${ }^{25}$ Douglas again wrote for the Court in Follet v. Town of $\mathrm{McCormick},{ }^{26}$ which held violative of free exercise of religion a municipal ordinance that imposed a flat license tax on book agents. In that case, the ordinance had been applied to a Jehovah's Witness preacher who earned his living by distributing religious tracts in his home town. The Supreme Court of South Carolina felt that the Murdock case was inapplicable because it involved itinerant evangelists. However, Douglas explained that the itinerant nature of the colporteurs' activities in Murdock was mentioned merely to emphasize the impact of the license tax. He then repeated the broader rationale of Murdock as controlling: " '[T] he power to tax the exercise of a privilege is the power to control or suppress its enjoyment." "27

In Fowler v. Rhode Island, ${ }^{28}$ the Court, again per Justice Douglas, held that a municipal ordinance violates the First Amendment when so construed and applied as to penalize a Jehovah's Witness minister for preaching at a peaceful religious meeting held in a local park. The ordinance provided that no person could address a religious meeting in a public park. But other denominations could and did conduct religious services there. The Court decided that the city could not prohibit a Jehovah's Witnesses service merely because it included a sermon. Douglas stated:

[I]t is no business of courts to say that what is a religious practice or activity for one group is not religion under the protection of the First Amendment. Nor is it in the competence of courts under our constitutional scheme to approve, disapprove, classify, regulate, or in any manner control sermons delivered at religious meetings. Sermons are as much a part of a religious service as prayers. ${ }^{29}$

24. 319 U.S. 141 (1943).

25. Id. at 149. See also two decisions in which Justice Douglas acquiesced: Marsh v. Alabama, 326 U.S. 501 (1946) (a state cannot prohibit the distribution of religious literature on the sidewalk of a company-owned town); Tucker v. Texas, 326 U.S. 517 (1946) (federal government-owned village).

26. 321 U.S. 573 (1944).

27. Id. at 576-77. See also Jamison v. Texas, 318 U.S. 413 (1943) ; Largent v. Texas, 318 U.S. 418 (1943). Cf. Justice Douglas' vote with the majority in Prince v. Massachusetts, 321 U.S. 158 (1944), upholding the defendant's conviction for violation of the child labor laws by taking her nine-year old ward onto the streets to distribute religious literature in the evening. For a comprehensive review of the proselyting cases, see Kurland, Of Church and State and the Supreme Court, 29 U. Crir. L. Rev. 1, 36-62 (1961).

28. 345 U.S. 67 (1953).

29. 345 U.S. at 70. In Saia v. New York, 334 U.S. 558 (1948), a 5-4 decision, Justice Douglas, for the Court, held unconstitutional on its face a city ordinance which forbade the use of sound amplification devices in public places except with permission of the 
In a different kind of case, the reach of Douglas' fidelity to religious liberty was put to sterner test. Thus in the famous second flag-salute case, $W$ est $V$ irginia State Bd. of Educ. v. Barnette, ${ }^{30}$ decided almost a year before the landings in Normandy, the Court, writing through Mr. Justice Jackson, was content to rest its condemnation of the compulsory salute on the rationale that

... [T $]$ he action of the local authorities in compelling the flag salute and pledge transcends constitutional limitations on their power and invades the sphere of intellect and spirit which it is the purpose of the First Amendment to our Constitution to reserve from all official control. ${ }^{31}$

But apparently this did not fully satisfy Justice Douglas, who argued that the statute failed to accord full scope to the freedom of religion secured by the First and Fourteenth Amendments. Concurring with Mr. Justice Black, he emphasized the right to follow a conscience that is predicated on religious convictions:

Neither our domestic tranquility in peace nor our martial effort in war depend on compelling little children to participate in a ceremony which ends in nothing for them but a fear of spiritual condemnation. If, as we think, their fears are groundless, time and reason are the proper antidotes for their errors. The ceremonial, when enforced against conscientious objectors, more likely to defeat than to serve its high purpose, is a handy implement for disguised religious persecution. As such, it is inconsistent with our Constitution's plan and purpose. ${ }^{32}$

In United States $v$. Ballard ${ }^{33}$ followers of the "I Am" movement were charged with use of the mails to defraud through representations, involving their religious beliefs, which allegedly were known by them to be false. Justice Douglas, again writing for the Court, held that the First Amendment's guarantee of religious freedom required the trial judge to withhold from the jury all questions concerning the truth or falsity of such religious beliefs. Mountaineer met judge in this significant dialogue:

Heresy trials are foreign to our Constitution. Men may believe what they cannot prove. They may not be put to the proof of their religious doctrines or beliefs. Religious experiences which are as real as life to some may be incomprehensible to others. Yet the fact that they may be beyond the ken of mortals does not mean that they can be made suspect before the law. Many take their gospel from the New Testament.

Chief of Police. The ordinance prescribed no standards for the exercise of his discretion. The rationale was that it established a previous restraint on free speech. Among the freedom of religion cases he cited was the famous Cantwell v. Connecticut, 310 U.S. 296 (1940), where Mr. Justice Roberts had written for the unanimous Court. See also Niemotko v. Maryland, 340 U.S. 268 (1951), where, in an opinion by Mr. Chief Justice Vinson, convictions for making proselyting speeches in a public park without having obtained a permit from city officials were reversed. But cf. Cox v. New Hampshire, 312 U.S. 569 (1941).
30. 319 U.S. 624 (1943).
31. Id. at 642 .
32. Id. at 644.
33. 322 U.S. 78 (1944). 
But it would hardly be supposed that they could be tried before a jury charged with the duty of determining whether those teachings contained false representations. The miracles of the New Testament, the Divinity of Christ, life after death, the power of prayer are deep in the religious convictions of many. If one could be sent to jail because a jury in a hostile environment found those teachings false, little indeed would be left of religious freedom. The Fathers of the Constitution were not unaware of the varied and extreme view of religious sects, of the violence of disagreement among them, and of the lack of any one religious creed on which all men would agree. They fashioned a charter of government which envisaged the widest possible toleration of conflicting views. Man's relation to his God was made no concern of the state. He was granted the right to worship as he pleased and to answer to no man for the verity of his religious views. The religious views espoused by respondents might seem incredible, if not preposterous, to most people. But if those doctrines are subject to trial before a jury charged with finding their truth or falsity, then the same can be done with the religious beliefs of any sect. When the triers of fact undertake that task, they enter a forbidden domain. ${ }^{34}$

And then the mountaineer-judge forthrightly enunciated the American ideal of non-preferment for any religious denomination and, it would seem, the ideal of the preferred status for religion qua religion: "The First Amendment does not select any one group or any one type of religion for preferred treatment. It puts them all in that position."35 Did this foreshadow Douglas' famous statement in Zorach v. Clanson, "We are a religious people whose institutions presuppose a Supreme Being" ?36

34. Id. at 86-87. Douglas has said:

Henry VIII banned the reading of the Bible in church. He decreed that the common people should not read the New Testament in English. Why? The Bible contains strong ideas of liberty, ideas that might well make the common folk restless.

Douglas, We the Judges 309 (1956).

35. United States v. Ballard, 322 U.S. 78, 87 (1944). See also Kedroff v. St. Nicholas Cathedral, 344 U.S. 94 (1952), holding that New York legislation which transferred the administrative control of the Russian Orthodox churches from the Moscow authority to authorities selected by a convention of the North American churches violates the Free Exercise Clause. Justice Douglas, while concurring in the Court's opinion, also joined the opinion of Mr. Justice Frankfurter wherein it is stated:

The long, unedifying history of the contest between the secular state and the church is replete with instances of attempts by civil government to exert pressure upon religious authority. Religious leaders have often made gestures of accommodation to such pressures. History also indicates that the vitality of great world religions survived such efforts. In any event, under our Constitution it is not open to the governments of this Union to reinforce the loyalty of their citizens by deciding who is the true exponent of their religion.

344 U.S. at 124-25. A second case, Kreshik v. St. Nicholas Cathedral, 363 U.S. 190 (1960), followed Kedroff on the ground that the Free Exercise principles bind the judiciary as well as the legislature. In Kreshik, the New York Court of Appeals had ordered a retrial on a common law issue assertedly left open by the United States Supreme Court's invalidation of the statutory basis of the first decision.

36. 343 U.S. 306, 313 (1952). 
Justice Douglas wrote for the Court in Girouard v. United States ${ }^{37}$ which overruled earlier cases to hold an alien entitled to citizenship who was willing to take the oath of allegiance and serve in the army as a non-combatant but was unwilling to bear arms. This required courage, for it was over the vigorous dissent of as eminent a libertarian as Mr. Chief Justice Stone (the only dissenter from the compulsion sustained in the First Flag Salute Case ${ }^{38}$ ), who was convinced that Congress had adopted the rule of the earlier cases. Douglas' realism prevailed in the observation that others than bearers of arms also defend their country: "The nuclear physicists who developed the atomic bomb, the worker at his lathe, the seamen on cargo vessels, construction battalions, nurses, engineers, litter bearers, doctors, chaplains - these, too, made essential contributions. And many of them made the supreme sacrifice." ${ }^{39} \mathrm{He}$ then proclaims a faith that makes a country worth dying for:

The struggle for religious liberty has through the centuries been an effort to accommodate the demands of the State to the conscience of the individual. The victory for freedom of thought recorded in our Bill of Rights recognizes that in the domain of conscience there is a moral power higher than the State. Throughout the ages, men have suffered death rather than subordinate their allegiance to God to the authority of the State. Freedom of religion guaranteed by the First Amendment is the product of that struggle. . . .40

In a sense the hardiest test of the reaches of his devotion to religious liberty arose in Poulos v. New Hampshire ${ }^{41}$ - hardiest because its problem directly concerns the potentials of strife and violence. What had Douglas really meant when he noted that "Throughout the ages, men have suffered death rather than subordinate their allegiance to God to the authority of the State"? In Poulos the Court upheld the state's determination that a city ordinance which forbade the holding of a religious meeting in a city park without a permit was not invalid on its face. The Court reasoned that the licensing officials had no discretion as to granting permits, no power to discriminate, and no control over speech. The Court held that the appropriate remedy for a Jehovah's Witness claiming arbitrary denial of a license was judicial review of the licensing official's action; he could not violate the ordinance by holding the meeting without a license, and defend a criminal charge on First Amendment grounds. This was not good enough for Justice Douglas. He argued that if denial of the right to speak had been contained in a statute, the defendant would have been entitled to flout the law, exercise his consitutional right

37. 328 U.S. 61 (1946).

38. Minersville School Dist. v. Gobitis, 310 U.S. 586, 601 (1940).

39. $32 S$ U.S. 61,64 (1946).

40. Id. at 68. See also In re Summers, 325 U.S. 561 (1945) (refusal of admission to the bar of one unable, because of conscientious scruples against wartime service in the state militia, to take the required oath, did not violate the First and Fourteenth Amendments); Justices Douglas, Murphy and Rutledge concurred in the dissenting opinion of Mr. Justice Black.

41. 345 U.S. 395 (1953). 
to free speech, and when criminally tried, to defend on the ground that the the law was unconstitutional. "If the citizen can flout the legislature when it undertakes to tamper with his First Amendment rights, I fail to see why he may not flout the official or agency who administers a licensing law designed to regulate the exercise of the right of free speech."42

This is dangerous doctrine. It puts society to severe strain in that it tends to postpone the orderly event, i.e., the judicial process, until after culmination of the potential disorder. It is doctrine akin to that which, in the area of the press' notorious conduct in sensational criminal cases, has engendered decisions all but dissipating the judicial contempt power with the result, as Mr. Justice Jackson warned, of making insecure all rights by jeopardizing the indispensable one of a fair trial. ${ }^{43}$ And even as this doctrine strains society, it puts the individual to gruelling test, for it extends his personal gamble into the domain of the criminal law's dire threat. But in an area of conscience's inviolability - such as the right of religious freedom — will history not abide the mountaineer's conclusion that the risk is worth running?

However, no one has yet been wise enough to devise a formula that permits all avoidance of governmental impingement upon the free exercise of religion in deed as in thought. That the ideal of Mr. Justice Jackson in Ballard - "I would dismiss the indictment and have done with this business of judicially examining other people's faiths" 44 - is not wholly attainable, or in any event not yet attained, had to be acknowledged by Justice Douglas himself in Cleveland $v$. United States. ${ }^{45}$ There, defendants were members of a Mormon sect known as Fundamentalists who practiced polygamy. They had plural wives and transported them across state lines. They were convicted of violation of the Mann Act which makes an offense the transportation in interstate commerce of "any woman or girl for the purpose of prostitution or debauchery, or for any other immoral purpose." First holding that polygamous practices are within the act, Justice Douglas for the Court quoted from Mormon Church v. United States ${ }^{46}$ that "The organization of a community for the spread and practice of polygamy is, in a measure, a return to barbarism.

42. Id. at 423. Compare Chaplinsky v. New Hampshire, 315 U.S. 568 (1942) (cursing a public official is not the exercise of religion) ; but cf. Kunz v. New York, 340 U.S. 290 (1951) (defendant's application for a permit to hold religious meetings on New York City streets unconstitutionally denied, despite his previous denunciation of other religious beliefs).

43. The right of the people to have a free press is a vital one, but so is the right to have a calm and fair trial free from outside pressures and influences. Every other right, including the right of a free press itself, may depend on the ability to get a judicial hearing as dispassionate and impartial as the weakness inherent in men will permit.

Craig v. Harney, 331 U.S. 367, 394-95 (1947) (Jackson, J., dissenting). See generally Berger, Consiructive Contempt: A Post-Mortem, 9 U. CHI. L. REv. 602 (1942).

44. 322 U.S. 78, 95 (1944).

45. 329 U.S. 14 (1946).

46. 136 U.S. 1 (1890). 
It is contrary to the spirit of Christianity and of the civilization which Christianity had produced in the Western world." 47 Then overruling the contention that the requisite criminal intent was lacking because defendants were motivated by a religious belief, he said:

That defense claims too much. If upheld, it would place beyond the law any act done under claim of religious sanction. But it has long been held that the fact that polygamy is supported by a religious creed affords no defense in a prosecution for bigamy. ... Whether an act is immoral within the meaning of the statute is not to be determined by the accused's concepts of morality. Congress has provided the standard. 48

It is much more difficult for a libertarian to be eloquent in overruling a claim to religious freedom than in sustaining it.

Perhaps the furthest affirmative reach of Justice Douglas' philosophy that "The institutions of our society are founded on the belief that there is an authority higher than the authority of the State; that there is a moral law which the State is powerless to alter; that the individual possesses rights, conferred by the Creator, which government must respect" 49 came in the four "Blue Law" cases of $1961 .{ }^{50}$ In two of them appellants had standing to raise, so far as the First Amendment was concerned, only Establishment Clause claims ${ }^{51}$ but in the other two the Free Exercise Clause was also available. $^{52}$ Thus in Brannfeld $v$. Brown ${ }^{53}$ the merchants complaining of the Pennsylvania criminal statute which forbade the retail sale on Sunday of their commodities, were members of the Orthodox Jewish faith. Their argument, as epitomized by Mr. Justice Stewart, was that "Pennsylvania had passed a law which compels an Orthodox Jew to choose between his religious faith and his economic survival."54 But the Court upheld the law:

[I] $f$ the State regulates conduct by enacting a general law within its power, the purpose and effect of which is to advance the State's secular goals, the statute is valid despite its indirect burden on religious observance unless the State may accomplish its purpose by means which do not impose such a burden.55

The essence of Justice Douglas' long dissent is in the trenchant paragraph below - a paragraph which immediately follows upon his observation that

47. Id. at 49 .

48. 329 U.S. 14, 20 (1946).

49. McGowan v. Maryland, 366 U.S. 420, 562 (1961) (Douglas, J., dissenting).

50. McGowan v. Maryland. 366 U.S. 420 (1961) ; Two Guys v. McGinley, 366 U.S. 582 (1961); Braunfeld v. Brown, 366 U.S. 599 (1961); Gallagher v. Crown Kosher Super Market, 366 U.S. 617 (1961).

51. McGowan v. Maryland, supra note 50; Two Guys v. McGinley ${ }_{x}$ supra note 50.

52. Braunfeld v. Brown, supra note 50; Gallagher v. Crown Kosher Super Market, supra note 50.

53. 366 U.S. 599 (1961).

54. Id. at 616 (Stewart, J., dissenting).

55. Id. at 607 . 
most people are as unconscious of their value patterns as they are of the oxygen they breathe. Does not its simplicity, directness and candor remind one of the talk of the lumberjack, fisherman, farmer, sailor - or mountaineer?

The issue of these cases would therefore be in better focus if we imagined that a state legislature, controlled by orthodox Jews and Seventh-Day Adventists, passed a law making it a crime to keep a shop open on Saturdays. Would a Baptist, Catholic, Methodist, or Presbyterian be compelled to obey that law or go to jail or pay a fine? Or suppose Moslems grew in political strength here and got a law through a state legislature making it a crime to keep a shop open on Fridays. Would the rest of us have to submit under the fear of criminal sanctions ?56

This dissent gains nothing by also invoking the Establishment Clause. It is adequately supported by principles validly derived from the Free Exercise Clause. But in Arlan's Dept. Store v. Kentucky ${ }^{57}$ Justice Douglas insists upon carrying forward Establishment Clause thinking to dissent from the Court's otherwise unanimous dismissal, for want of a substantial federal question, of an appeal from convictions for employing persons on Sunday in violation of a Kentucky statute. Arlan's differed from Braunfeld because in Kentucky those who actually observe the Sabbath on a day of the week other than Sunday are exempt from the penal provisions. The Douglas dissent condemns, in the name of the Establishment Clause, Sunday closing laws even when the conscience of a minority member is protected by the option of an alternate day. The extremism of this notion of establishment, at least from the historical viewpoint, is indicated by the fact that no American court ever has held a Sunday closing law unconstitutional - with the single exception of a California case soon overruled. ${ }^{58}$ Justice Douglas thus incurs the danger of imposing an unjustified limitation upon the religious freedom of the majority - a danger to which in my opinion he has explicitly succumbed in other cases, where he reads the Establishment Clause to eradicate all religion in public life. This view not only lacks historicity but is in the end to undermine the First Amendment's primary purpose, protection for the free exercise of religion. For what happens to freedom of religion if, for example, government does not make available to isolated military personnel or incarcerated prisoners the services of chaplains? What happens to it if a public park, open generally to civic and community events, is closed to religious activities because government cannot aid religion? The conclusion seems inescapable that Justice Douglas, at one time our strongest judicial protector

56. McGowan v. Maryland, 366 U.S. 420, 565 (1961). Justice Douglas' dissenting opinion applied to all four of the "Blue Law" cases cited in note 50 stpra.

57. 371 U.S. 218 (1962).

58. Ex parte Newman, 9 Cal. 502 (1858), ozcrruled, Ex parte Andrews, 18 Cal. 679 (1861) ; see Louisell and Jackson, infra note 66 , at 782.

A trial court did enjoin enforcement of certain sections of the Massachusetts Sunday closing law as unconstitutional, but was reversed in Gallagher v. Crown Kosher Super Market, 366 U.S. 617 (1961). 
of religious freedom, has become the spokesman for an absolutist interpretation of the Establishment Clause.

How is one to explain why so ardent a proponent and so eloquent an expounder of the American ideal of religious freedom - and when occasion demanded, so courageous a dissenter - should have been swept away with the majority to the absolutist viewpoint of establishment? For in Everson $v$. Board of Educ.,59 Justice Douglas, although voting with the majority, I think rightly, to permit reimbursement of bus fares to parents of children attending nonprofit private and parochial school, unfortunately also acquiesced in the Court's fateful dictum, which has plagued its path in the religion area ever since: "Neither a state nor the Federal Government can ... a aid all religions ...."60 And when this dictum ripened into holding in McCollum v. Board of Educ., ${ }^{61}$ the Illinois "released time" case with instruction on public school

59. 330 U.S. 1 (1947).

60. Id. at 15 . The full dictum is :

The "establishment of religion" clause of the First Amendment means at least this: Neither a state nor the Federal Government can set up a church. Neither can pass laws which aid one religion, aid all religions, or prefer one religion over another. Neither can force nor influence a person to go to or to remain away from church against his will or force him to profess a belief or disbelief in any religion. No person can be punished for entertaining or professing religious beliefs or disbeliefs, for church attendance or nonattendance. No tax in any amount, large or small, can be levied to support any religious activities or institutions, whatever they may be called, or whatever form they may adopt to teach or practice religion. Neither a state nor the Federal Government can, openly or secretly, participate in the affairs of any religious organizations or groups and vice versa. In the words of Jefferson, the clause against establishment of religion by law was intended to erect "a wall of separation between church and State."

Id. at $15-16$.

61. 333 U.S. 203 (1948). In this case an Illinois school board, in accordance with Illinois law which, of course, also provided for compulsory elementary education, adopted a program that permitted teachers representing various religious denominations to come to the school premises. The teachers were paid, not by the school system, but by the respective denominations. Pursuant to parental approval, the children who wanted the religious instruction were excused from other studies while the remaining children continued in their regular secular pursuits. The McCollum child was not allowed by his parents to attend the religious classes and, as one of the few who remained behind or went to another room, allegedly suffered embarrassment. His parents brought mandamus to terminate the program, and the Court, by an eight to one vote, condemned the Illinois plan, deeming it to be an unwarranted use of public property and the compulsory primary education laws for religious purposes. The Court held the plan was a prohibited "establishment of religion." Four opinions were written. Mr. Justice Black wrote for the Court. Mr. Justice Frankfurter wrote a separate opinion, in which Justices Jackson, Rutledge and Burton joined. (Justices Rutledge and Burton also concurred in the Court's opinion). Mr. Justice Jackson also wrote a concurring opinion. Douglas noted nothing to indicate dissatisfaction with the Court's opinion. In his AN ALmanac of Liberty 261 (1954), he said of McColltun:

The program was held unconstitutional by a divided Court, as "a utilization of the tax-established and tax-supported public school system to aid religious groups to spread their faith." The use of the public school rooms and of the public school 
premises, it was with the silent acquiescence of Justice Douglas. Of course, the error of the extreme "no aid" rationale was not exclusively nor even explicitly his; it was the error of the Court; but for a man of such outspoken convictions, silence bespeaks -support for the Court's rationale.

One writes hesitantly of serious error by the Court, especially a lawyer who respects it as the indispensable condition of our federalism and loves it as the best protector of our freedom, and who sees in it over its long history one of the world's great moral teachers. Yet hesitancy would forestall honest and earnest criticism in vital matters only at the price of cowardice. Such cowardice is not only inherently shameful but, worse, ultimately destructive of the prestige and influence of the Court. The rationale of Lincoln's reconciliation, in his First Inaugural, of judicial supremacy with the essentials of democratic society, has not diminished but rather increased in its pertinency in the current social scene. ${ }^{62}$ If the Court is the indispensable brake on the excesses of democracy, criticism is the essential safety valve for the Court's own excesses. Without such criticism the viability of a republican tripartite system is in jeopardy. ${ }^{63}$ And it is my conviction that the Court's absolutist in-

machinery to help sectarian groups in their religious instruction was the fatal feature of the scheme.

Mr. Justice Reed in dissent based his opinion primarily on the history of past practices as authoritatively providing the meaning of "establishment of religion." He noted the extensive cooperation that government has always given religion in the United States and concluded that "devotion to the great principle of religious liberty should not lead us into a rigid interpretation of the constitutional guarantee that conflicts with accepter habits of our people." 333 U.S. at 256.

62. 4 Basler, The Collected Works of Abraham Lincoln 262, 268 (1953):

I do not forget the position assumed by some, that constitutional questions are to be decided by the Supreme Court; nor do I deny that such decisions must be binding in any case, upon the parties to a suit, as to the object of that suit, while they are also entitled to very high respect and consideration, in all parallel cases by all other departments of the government. And while it is obviously possible that such decision may be erroneous in any given case, still the evil effect following it, being limited to that particular case, with the chance that it may be overruled and never become a precedent for other cases, can better be borne than could the evils of a different practice. At the same time the candid citizen must confess that if the policy of the government upon vital questions affecting the whole people, is to be irrevocably fixed by decisions of the Supreme Court, the instant they are made, in ordinary litigation between parties in personal actions, the people will have ceased to be their own rulers, having, to that extent, practically resigned their government, into the hands of that eminent tribunal. Nor is there, in this view, any assault upon the court, or the judges. It is a duty, from which they may not shrink, to decide cases properly brought before them; and it is no fault of theirs if others seek to turn their decisions to political purposes.

63. Dean Griswold has put well the principles which should govern criticism of the Court:

An institution charged with the role which the Supreme Court has successfully filled for so many years is entitled to our respect and understanding. If one criticizes the Court (as people have always done in the past, and should continue to do in the future), it should be essentially for the purpose of trying to contribute 
terpretation of the Establishment Clause in the dictum in Everson and in the rationale of, e.g., McCollum, Engel v: Vitale ${ }^{64}$ and School Dist. of Abington v. Schempp ${ }^{65}$ is a mistake of major proportions, ranking with several of the Court's darker moments. ${ }^{66}$

For me, Zorach v. Clauson ${ }^{67}$ engendered great hope that the Court under the leadership of Justice Douglas had found its way again. In that, the second "released time" case, he distinguished $M c$ Collum on the ground that there "classrooms were turned over to religious instructors," whereas in Zorach, the "released time" plan involved "neither religious instruction in public school classrooms nor the expenditure of public funds." 68 True, the Zorach opinion was not fully satisfactory on the latter point, in that Zorach also involved use of public school machinery existent under compulsory school attendance laws, and hence some public financing albeit minimal. In fact Mr. Justice Jackson, dissenting in Zorach, said that the "distinction attempted between [ $\mathrm{McCollum}$ ] ... and [Zorach $]$... is trivial, almost to the point of cynicism. . . ." and that Zorach's "judgment will be more interesting to students of psychology and of the judicial process than to students of constitutional law." 69

to that respect and to that understanding. The debt which we all owe to the Court is far greater than any individual can repay. Criticism of decisions of the Court or opinions of its members should be offered as an effort to repay that debt, and with the thought that conscientious criticism may be an aid to the Court in carrying out its difficult and essential task.

Griswold, Absolute is it the Dark - A Discussion of The Approach of the Supreme Court to Constitutional Questions, 8 UTAн L. Rev. 167 (1963); see also Freund, The Suprome Cout Under Attack, 25 U. PrrT. L. Rev. 1 (1963); cf. Kurland, The School Prayer Cases, in The Wall Between Churce and State 142, 178 (Oaks ed. 1963). Respecting criticism from within the Court, the Justice has stated himself:

... Short range changes in constitutional doctrine are not unusual, either as a result of a change in the Bench or a change in the view of the Justices themselves. And either seems a more honorable, a more frank course than failure to speak up or the announcement of a constitutional doctrine that a majority disapproves. Douglas, The Bill of Rights is Not Entough, in The GREAT Rigets, 115, 144 (Cahn ed. 1963).

64. 370 U.S. 421 (1962).

65. 374 U.S. 203 (1963).

66. In my view this absolutist interpretation is comparable, in its lack of interpretative accuracy, to Swift v. Tyson, 41 U.S. (16 Pet.) 1 (1842), corrected ninety-six years later by Erie R.R. Co. v. Tompkins, 304 U.S. 64 (1938); it is as unrealistic as Pollock v. Farmers' Loan \& Trust Co., 157 U.S. 429 , affirmance upheld on rehearing 158 U.S. 601 (1895), corrected by the Sixteenth Amendment; it is as inconsistent with the American ethos as Dred Scott's Case, 60 U.S. (19 How.) 393 (1857), reversed by the Civil War. See Louisell and Jackson, Religion, Theology, and Public Higher Education, 50 Calif. L. Rev. 751, 758 (1962); Corwin, The Suprene Court as National School Board, 14 LAw \& Contemp. Prob. 3, 9-22 (1949); Kauper, Prayer, Public Schools and the Suprcme Court, 61 Mrch. L. Rev. 1031, 1052 (1963) ; Sutherland, Establishment According to Engel, 76 Harv. L. REv. 25, 35-39 (1962); but see Cahn, The "Establishment of Religion" Puzsle, 36 N.Y.U. L. REv. 1274 (1961).

67. 343 U.S. 306 (1952).

68. Id. at 308-09.

69. Id. at 325 . 
But Zorach's common-sense recognition of the historic realities of American life, its adjustment of the interests of parts to the whole, and its feel for meaningful relationship between the Establishment and Free Exercise Clauses were gusts of pure air at mountaintop. Crisp and fresh, they dissipate sophistry and judicial make-believe like "the froth of life that would disappear on the wings of the northwester on Old Snowy."70 Can anyone, whatever his personal sentiments and convictions, recall the outpouring of religious feeling and devotion following the assassination of the President, on occasions private and public, in churches and chapels, cathedrals and synagogues, shrines and temples, in homes and on the streets, in village squares and city parks, on federally licensed radio and television, in grammar schools and universities, public and private, in the Army, Navy, Marine Corps and Air Forces, wherever the American flag flies, and now on the new Kennedy memorial coin which still carries the inscription "In God We Trust," without knowing that in Zorach Douglas truthfully expressed a fundamental of the American ethos?

There cannot be the slightest doubt that the First Amendment reflects the philosophy that Church and State should be separated. . . The First Amendment, however, does not say that in every and all respects there shall be a separation of Church and State. Rather, it studiously defines the manner, the specific ways, in which there shall be no concert or union or dependency one on the other. That is the common sense of the matter. Otherwise the state and religion would be aliens to each other - hostile, suspicious, and even unfriendly. ${ }^{71}$

We are a religious people whose institutions presuppose a Supreme Being. We guarantee the freedom to worship as one chooses. ... When the state encourages religious instruction or cooperates with religious authorities by adjusting the schedule of public events to sectarian needs, it follows the best of our traditions. ... To hold that it may not would be to find in the Constitution a requirement that the government show a callous indifference to religious groups. That would be preferring those who believe in no religion over those who do believe. Government may not finance religious groups nor undertake religious instruction nor blend secular and sectarian education nor use secular institutions to force one or some religion on any person. But we find no constitutional requirement which makes it necessary for government to be hostile to religion and to throw its weight against efforts to widen the effective scope of religious influence. ${ }^{72}$

But the hopes engendered by Zorach that the Court again was on a track strong enough to sustain the heavy freight of the religious issues, and at

70. Douglas, Of Men and Mountains 212 (1950).

71. 343 U.S. 306,312 (1952).

72. Id. at 313-14; see Religion ANn ANerican Soctety 40 (Fund for the Republic, 1961). In his An Almanac of Liberty 298 (1954), Justice Douglas said of Zorach: The First Amendment does not require the state and the churches to be aliens to each other. Policemen can help parishioners into their churches, prayers can be said in legislatures, Thanksgiving Day can be proclaimed, "So help me God" can be used in the courtroom without violating the First Amendment.

See also Douglas, We the Junges 338 (1956). 
least heading in the direction of wise decisions, were frustrated by its rationale in Engel v. Vitale, ${ }^{73}$ the New York Regents Prayer Case. There absolutist notions of the meaning of the Establishment Clause carried the principle that "Neither a state nor the Federal Government ... can pass laws which ... aid all religions"74 almost to logic's ultimate limits in the Court's rationale, and certainly so in the concurrence of Justice Douglas. Perhaps the Zorachborn hopes were too sanguine; in any event perhaps one should have been forewarned by Torcaso v. Watkins"75 "no aid" to religion formula, in which Justice Douglas again silently acquiesced. In that case the Court apparently equated for all First Amendment purposes theistic and nontheistic religions. Thereby the Court - since on its own premise government cannot aid any or all religion - logically had placed secular humanism's tenet of Human Brotherhood as much beyond the pale for the classroom as the principles of the Fatherhood of God and Brotherhood of Man in the Jewish and Christian traditions - leaving public schools without any philosophical basis for inculcating values. ${ }^{78}$

Perhaps therefore the Court's rationale in Engel was to have been anticipated; perhaps one should be reconciled that an error of this kind often takes at least a generation to correct. But what of Justice Douglas' concurrence especially in the light of Zorach's "We are a religious people whose institutions presuppose a Supreme Being"? For in his Engel concurring opinion, he would root out apparently every vestige, direct and indirect, of religion in public affairs. He would hold unconstitutional, as an establishment of religion, each of the ways in which our government, federal and state, is "honeycombed"

73. 370 U.S. 421 (1962).

74. This dictum first appeared in Everson, 330 U.S. 1, 15 (1947), was quoted in McCollum, 333 U.S. 203, 210 (1948), was partially paraphrased in Zorach, 343 U.S. 306, 314 (1952), and was quoted again in Torcaso v. Watkins, 367 U.S. 488, 492-93 (1961). There seemed to be a gleam of hope in the fact of its omission from Engel; see Louisell and Jackson, supra note 66, at 760 n.38. But it was quoted again in Abington, 374 U.S. 203,216 (1963). When the current "no aid" notion is superseded by a realistic accommodation of the Establishment and Free Exercise Clauses, accordant with the historic paramountcy of religious freedom, much credit will be due Mr. Justice Stewart, who stood ground for reason and history in his dissents in Engel, 370 U.S. 421, 444 (1962), and Abington, 374 U.S. at 308. See also his opinion concurring in the result in Sherbert 2. Verner, 374 U.S. 398, 413 (1963). He stood alone in Engel and Abington; but so did Justice (later Chief Justice) Stone in Minersville School Dist. v. Gobitis, 310 U.S. 586, 601 (1940) (first flag-salute case), overruled, West Virginia State Board of Education v. Barnette, 319 U.S. 624 (1943) (second flag-salute case). Moreover, once again there is hope in the concurring opinions of Justices Brennan and Goldberg in Abington, 374 U.S. at 230,305 , that the most extreme threats implicit in the "no aid" notion - and made explicit by Douglas in his Engel concurrence, 370 U.S. at 437 - will bow to the realities of American history.

75. 367 U.S. 488 (1961). Of course no issue is taken with the holding of the Court that the Free Exercise Clause precludes a religious test as a qualification for public office. The objectionable thing was the invoking, 367 U.S. at 492-93, of the rigid "no aid" to religion formula first stated in Everson, 330 U.S. 1, 15-16 (1947).

76. See Louisell and Jackson, stupra note 66, at 759; Kauper, supra note 66, at 1054. 
with financing of religious exercises. ${ }^{77}$ Borrowing another's words, he paraded a long list of activities that should be banned. Even a partial recapitulation of the federal activities he mentioned is imposing: ${ }^{78}$ chaplains in both Houses of Congress and in the armed services; compulsory chapel at the service academies; religious proclamations by the President; use of the Bible for oaths; funds for the education of veterans at denominational schools, and for lunches for children in such schools; the references to God on coins and in the pledge of allegiance; Bible reading in the schools of the District of Columbia (its removal has now been ordered in state schools by Abington School Dist. v. Schempp) $;^{79}$ taxation exemption for religious organizations; deductions for income tax purposes of contributions to religious organizations.

How would such a banning as this comport with being "a religious people" whose needs as such - so Zorach taught - were to be accommodated by the state? In trying to answer such a question, one must strive mightily to be fair. Certainly concurrence in the Court's actual conclusion in Engel could have been consistent with Zorach's rationale. If Justice Douglas had concluded, after deliberate appraisal of the facts with appropriate deference to the on-the-spot fact finders, ${ }^{80}$ that public school prayer for young children is so inherently coercive as to violate the free exercise of religion, an opinion so proclaiming might have matched in reasonableness what he said in Barnette or Ballard or Girouard, and in eloquence the thoughts that came to him on the mountaintop. Moreover, let us assume that it is possible analytically to harmonize with Zorach even a concurrence in the Court's Establishment Clause rationale in Engel, at least to the extent it is grounded in the notion of prohibited governmental financing of religion. For, after all, the hub of the Douglas complaint about Engel's practices, repeated in Abington School Dist. $v$. Schempp, concerns their financing by government; and conceivably he thought such financing in Engel, albeit small, was more significant than in Zorach. Or perhaps in the Justice's concept, the financing in Zorach, unlike that in Engel. was "indirect" as apparently he thought it to be in Sherbert v. Verner," which

77. 370 U.S. 421,437 (1962).

78. Id. at 437 n.1, quoting Fellaran, The Lintrs of Freedom 40-41 (1959).

79. 374 U.S. 203 (1963).

80. Cf. Brown, Quis Custodiet Ipsos Custodes? - The School Prayer Cases, 1963 Supreme Court Review 1, 30 (1963).

81. 374 U.S. 398, 410 (1963) (concurring opinion). It is, however, indeed difficult to see how the teacher's leading of the prayer in Engel is any more a financing of religion than the teacher's activities in Zorach connected with release of students for religious instruction. In fact, in Engel Justice Douglas himself stressed that only a bare fraction of the teacher's time was given to the 22-word Regents' prayer. 370 U.S. 421, 441 (1962). Of course, if a reasonable balancing of values and interests were permitted, it would be relevant to suggest that the felt need for religious instruction plus the Free Exercise Clause's guarantees countervailed in Zorach against the relatively slight involvement of public financing; whereas even the slight financing involved in Engel, plus at least the possibility of psychological coercion of dissenting children, outweighs the majority's right to pray. But any such reasonable balancing is the very thing precluded by the absolutist "no aid" formula! 
held the free exercise of religion to be denied when unemployment benefits were withheld because of a religiously-based refusal to work on Saturday. But in any event, however much one juggles the contingencies, it is impossible honestly to acquit Justice Douglas of gross inconsistency. For however reconcilable his votes in Zorach and the subsequent cases, the fact remains that the raison d'etre for Zorach's accommodation between public and religious interests was that "Otherwise the state and religion would be aliens to each other - hostile, suspicious and even unfriendly." 82 As he said in Zorach, but for such accommodation

Municipalities would not be permitted to render police or fire protection to religious groups. Policemen who helped parishioners into their places of worship would violate the Constitution. Prayers in our legislative halls; the appeals to the Almighty in the messages of the Chief Executive; the proclamations making Thanksgiving Day a holiday; "so help me God" in our courtroom oaths - these and all other references to the Almighty that run through our laws, our public rituals, our ceremonies would be flouting the First Amendment. A fastidious atheist or agnostic could even object to the supplication with which the Court opens each session: "God save the United States and this Honorable Court."83

But those very things which in Zorach he saw as indispensable to accommodation of the religious needs of the people, in Engel he would obliterate. All aspects of religion in public life he would now hold unconstitutional, for the same reason he condemned the New York Regents' prayer.

In New York the teacher who leads in prayer is on the public payroll; and the time she takes seems minuscule as compared with the salaries appropriated by state legislature and Congress for chaplains to conduct prayers in the legislative halls. Only a bare fraction of the teacher's time is given to reciting this short 22-word prayer ["Almighty God, we acknowledge our dependence upon Thee, and we beg Thy blessings upon us, our parents, our teachers and our Country."], about the same amount of time our Crier spends announcing the opening of our sessions and offering a prayer for this Court. Yet for me the principle is the same, no matter how briefly the prayer is said, for in each of the instances given the person praying is a public official on the public payroll, performing a religious exercise in a governmental institution. It is said that the element of coercion is inherent in the giving of this prayer. If that is true here, it is also true of the prayer with which this Court is convened, and of those that open the Congress. Few adults, let alone children, would leave our courtroom or the Senate or the Hotise while those prayers are being given. Every such audience is in a sense a "captive" audience.

At the same time I cannot say that to authorize this prayer is to establish a religion in the strictly historic meaning of those words. A religion is not established in the usual sense merely by letting those who choose to do so say the prayer that the public school teacher leads. ${ }^{84}$

How can one explain such a volte-face? Has there been a true change of conviction, a belief that what he once thought to be constitutionally permissible

82. 343 U.S. 306, 312 (1952).

83. Id. at 312-13.

84. 370 U.S. $421,441-42$ (1962). 
- even required - by way of accommodation of the religious needs of the people, he now sees as an unconstitutional financing of religion? If so, one would expect an explicit acknowledgement of the change accordant with Douglas' usual directness and candor. Far from such an acknowledgement, Zorach's "We are a religious people whose institutions presuppose a Supreme Being" is repeated in the Engel concurring opinion, ${ }^{85}$ but without mention of those essential accommodations specified in Zorach as the natural consequences of that philosophy. Instead there is substituted without meaningful elucidation the vapid statement, "The First Amendment leaves the Government in a position not of hostility to religion but of neutrality."

The Engel concurrence does, however, contain one explicit recantation; Justice Douglas there regretted his vote in Everson, which made the majority of only five who permitted reimbursement to parents of bus money spent for children attending nonprofit private and parochial schools. He says in Engel:

The Everson case seems in retrospect to be out of line with the First Amendment. Its result is appealing, as it allows aid to be given to needy children. Yet by the same token, public funds could be used to satisfy other needs of children in parochial schools - lunches, books, and tuition being obvious examples. ${ }^{87}$

The foregoing illustrates how an interpretation of the Establishment Clause "not only insensitive, but positively wooden" 88 accords it "a meaning which neither the words, the history, nor the intention of the authors of that specific constitutional provision even remotely suggests" 89 and works at the end, as even well-intentioned absolutism so often does, to undermine freedom. ${ }^{90}$

85. Id. at 442 .

86. Id. at 443 .

87. Ibid. But see Cochran v. Louisiana State Bd. of Educ., 281 U.S. 370 (1930), holding that Louisiana did not violate due process by spending state funds for school books in parochial as well as public schools; the First Amendment freedoms were not discussed.

88. Sherbert v. Verner, 374 U.S. 398, 414 (1963) (Stewart, J, concurring in result).

89. Ibid.

90. "Doctrines are the most frightful tyrants to which men ever are subject, because doctrines get inside of a man's reason and betray him against himself." W. G. Sumner, quoted in Mendelson, On the Meaning of the First Amendment: Absolutes in the Balance, 50 CALIF. L. Rev. 821 (1962). Compare Mr. Justice Black:

I have no doubt myself that the ... [First Amendment], as written and adopted, intended that there should be no libel or defamation law in the United States under the United States Government, just absolutely none so far as I am concerned. ... [T] he same rule should apply to the states.

Justice Black and First Amendment "Absolutes": A Public Interviezv, 37 N.Y.U. L. Rev. 549, 557-58 (1962), with Lincoln's:

The world has never had a good definition of the word liberty .... We all declare for liberty; but in using the same word we do not all mean the same thing .... The shepherd drives the wolf from the sheep's throat, for which the sheep thanks the shepherd as a liberator, while the wolf denounces him for the same act as the destroyer of liberty....

Address at a Sanitary Fair in Baltimore, April 18, 1864 in Basler, Abrahadr Lincoln: His SpeEches AND Writings $748-49$ (1946). To make the contrast pertinent, may one 
Shortly after $\mathrm{McC}$ Collum the contention was seriously made that because government cannot establish a religion, it cannot permit a religious group to use a public park. ${ }^{01}$ And now, in the name of the Establishment Clause, as staunch a friend of religious liberty as Justice Douglas - who in Barnette insisted on resting his vote against the compulsory flag salute on the significance of the religiously predicated conscience - seems prepared to deny parochial school children such public benefits as transportation, lunches and books even though the reason for their school attendance is a religiously predicated conscience. $^{92}$

A cynic might see in all of this nothing but disappointed ambitions, and point out that Zorach was decided before the Democratic National Convention of 1952 had foreclosed the last reasonable hope of the Presidency - before the Presidential bug had lost its bite. Others may play the psychoanalyst to see in the self-contradictions of Douglas only repercussions of the stresses

justifiably think of "wolf" as today's libeller (emboldened by an absolutist interpretation of the First Amendment), and "shepherd" as our law of libel?

91. Milwaukee County v. Carter, 258 Wis. 139, 45 N.W.2d 90 (1950). But the holding was that the guarantee of free exercise of religion precludes an ordinance prohibiting religious activity in a public park. In County of Los Angeles v. Hollinger, 200 Cal. App. 2d 877, 19 Cal. Rptr. 648 (Dist. Ct. App. 1962), the producer of Verdi's opera Nabucodonosor (popularly "Nabucco") with an Old Testament theme, had to get a court order for payment of the contract price, the auditor having declined payment because of a suggestion that the contract aided religion.

92. In Sherbert v. Verner, 374 U.S. 398 (1963), Justice Douglas faced again what secms to me essentially the same problem in a different guise. There the Court under the Free Exercise Clause compelled South Carolina to pay unemployment compensation henefits to an employee whose unavailability for Saturday work resulted from her religious convictions as a Sabbatarian (although, admittedly, unavailability for such work for other reasons would have justified nonpayment). The deference for the widest range of religious conviction evidenced in Justice Douglas' concurring opinion is reminiscent of the best in his protection of religious liberty, and logically would seem to imply that, after all, his vote in Everson was right. There is, however, this ambiguous paragraph which urges a test that is merely mechanical and therefore discordant with the earthy realism which so often characterizes his writing:

This case is resolvable not in terms of what an individual can demand of government, but solely in terms of what government may not do to an individual in violation of his religious scruples. The fact that government cannot exact from me a surrender of one iota of my religious scruples does not, of course, mean that I can demand of government a sum of money, the better to exercise them. For the Free Exercise Clause is written in terms of what the government cannot do to the individual, not in terms of what the individual can exact from the government.

374 U.S. at 412. And his concurring opinion in Abington, 374 U.S. 203, 227, esp. 229 (1963), contains language about the significance of financing almost as extreme as his Engcl language. Abington and Sherbert were decided the same day, June 17, 1963. Also he voted to grant certiorari in Abernethy v. City of Irvine, 355 S.W.2d 159 (Ky. 1962) (a lease of a hospital building to a religious community of Benedictine Sisters does not constitute the transfer of public property to a religious organization in violation of the First Amendment), ccrt. denied, 371 U.S. 831 (1962). 
inherent in man's predicament. ${ }^{93}$ But I am neither cynic nor psychoanalyst, and I like to think that I see the truth seeker on the mountaintop, indifferent to his public image, willing to be "naked and alone, judged by the harmony of his soul, by his spiritual strength, by the purity of his heart." from the depths of a personality instinctively truthful the Justice has been trying to tell his brethren and all of us:

You cannot have it both ways. You cannot have your cake and eat it too. Either we are a religious people whose institutions presuppose a Supreme Being, or we are not. If to let "those who want to say a prayer say it" is Establishment of Religion, ${ }^{95}$ let us not be hypocritical but truthful to the end. If government cannot give any aid to religion, let us forthrightly put an end to all such aid. If we really mean "no aid" to religion, let us adhere to " $n o$ aid." I will show you the truth by logic's most violent device - reductio ad absurdum. On this I shall dissent as long as I am here, until you face the truth. ${ }^{26}$

In religion, as elsewhere in life, each generation produces its own special questions and answers. Theology's emphasis at any moment is a function of the current chief mischief. Today's theological emphasis is on love, not truth. Perhaps this helps explain why the truth seeker is not particularly idealized today. He is apt to be thought of as too much of a Savonarola for a tolerant

93. Is the weariness his writing sometimes now indicates but the reaction of any thinking man today who contrasts what so many religious people say with what they do? In his "Blue Law" dissent he borrows from John Cogley to say:

For the foreseeable future, it seems, the United States is going to be a threereligion nation. At the present time all three are characteristically "America," some think flavorlessly so. For religion in America is almost uniformly "respectable," bourgeois, and prosperous. In the Protestant world the "church" mentality has triumphed over the more venturesome spirit of the "sect." In the Catholic world, the mystical is muted in favor of booming organization and efficiently administered good works. And in the Jewish world the prophet is too frequently without honor, while the synagogue emphasis is focused in suburban togetherness. There are exceptions to these rules, of course; each of the religious communities continues to cast up its prophets, its rebels and radicals. But a Jeremiah, one fears, would be positively embarrassing to the present position of the Jews; a Francis of Assisi upsetting the complacency of American Catholics would be rudely dismissed as a fanatic; and a Kierkegaard, speaking with an American accent, would be considerably less welcome than Norman Vincent Peale in most Protestant pulpits.

366 U.S. at 565-66.

94. Douglas, Of Men and Mountatns 211 (1950).

95. Engel v. Vitale, 370 U.S. 421, 445 (1962) (Stewart, J., dissenting).

96. His language concurring in Sherbert v. Verner, 374 U.S. 398, 411-12 (1963), is pertinent:

Some have thought that a majority of the community can, through state action, compel a minority to observe their particular religious scruples so long as the majority's rule can be said to perform some valid secular function. That was the essence of the Court's decision in the Sunday Blue Law Cases [note 56, supra], a ruling from which $I$ then dissented ... and still dissent.

See Arlan's Dept. Store v. Kentucky, 371 U.S. 218 (1962); and text accompanying notes 57 supra and 102 infra. 
age. It seems that our generation appreciates the truth seeker as little as another generation did the prophet. Perhaps it is as a reaction to the venom of hatred that has so freely coursed in society's veins since that fateful Summer, 1914, that today we insist on love as religion's ultimate desideratum. ${ }^{97}$ Thus we are often reminded:

And now abideth faith, hope, charity, these three; but the greatest of these is charity. ${ }^{98}$

Religion pure and undefiled before God the Father is this: to give aid to orphans and widows in their tribulation, and to keep oneself unspotted from this world. ${ }^{99}$

Indeed, the Justice's own compendious travel books so abundantly document a philosophy of sympathy for mankind in its predicament, that for him, too, perhaps charity is the ultimate religious principle. ${ }^{100}$

But love, over the long pull of the human experience, has competitors for the first place. One competitor is truth. For we are also told, "You shall know the truth, and the truth shall make you free."101 Perhaps for mortals the seeking after truth is as much - dare one say even more? - a part of the Kingdom of Heaven than loving. And maybe truth, in an affluent and blasè society, can only be noticed if it is proclaimed unceasingly, blatantly, even violently.

Is it, then, as truth seeker that Justice Douglas comes to what for me is an absurd - a violently absurd - result in Arlan's?102 For he there condemns Sunday laws even when they protect the conscience of the dissenter. But absurd though this result be (and his eight colleagues dismissed for want of a substantial federal question), is it not the truth which he proclaims when he says: "The religious nature of this state regulation [prohibition of Sunday employment] is emphasized by the fact that it exempts 'members of a religious society' who actually observe the Sabbath on a day other than Sunday. The

97. See, e.g., Darcy, The Mind and Heart of Love 9-10 (1947).

98. 1 Coristhians 13:13 (King James).

99. 1 James 27 (Confraternity).

100. Douglas, Strange Lands and Friendly People 232-33 (1951); Douglas, Beyond the High Himadayas 197 (1952); Douglas, North From Malaya 248 (1953); Douglas, West of the Indus 375-85 (1958). See also Douglas, America Chalienged passim (1960) ; Douglas, Democracy's MaNifesto passim (1962). In Douglas, Russian JouRNEY 206-07 (1956), he tells of being invited by a Russian priest to share the pulpit, and delivering the sermon:

I took as my text the words printed on the streamer over the pulpit: "God is Love," 1 John 4:16 [King James]. I told these Russian peasants and workers that we in America worshipped the same God they worshipped. ... The words of Christ were our common inspiration. We worshipped through Him the same God. ... The gospel according to John is "That he who loveth God love his brother also."

101. John $8: 32$ (Confraternity).

102. 371 U.S. 218 (1962); see text accompanying notes 57 and 96 supra. 
law is thus plainly an aid to all organized religions . .."103 May not ultimately there be in this kind of mountaintop-like candor that coerces proclamation of truth, more real hope for a modus vivendi in the dilemma of American religious pluralism, than in judicial make-believe such as that Sunday laws are secular? "Old Snowy has no deceit or cunning. . . . It is as genuine and as impartial as the northwester."104

Perhaps, then, there is in Douglas on Religious Freedom something of an exegesis of what has always been for me the most troublesome, baffling and mystifying message in the Holy Bible:

And from the days of John the Baptist until now, the kingdom of heaven suffereth violence, and the violent bear it away. ${ }^{105}$

103. 371 U.S. at 220 (italics added).

104. Douglas, Of Men And Mountains 209 (1950).

105. Matthew 11:12 (Douay).

About the time of the Justice's appointment, I was invited by colleagues in practice in New York to a Yale banquet honoring him. It was a gala occasion, resplendent with wine and wit. As I recall, the Justice's remarks largely consisted of reading verses that were more or less spontaneously passed up to him. There must have been something about the way he read them - his capacity to distill the genuine from the trivial - that has enabled me to remember one to this day, more than twenty-five years later:

Mr. Justice, will you rule

The way you always used to drool?

Wesley Sturges says you will,

But my advice is, - Easy, Bill! 


\section{THE YALE LAW JOURNAL}

\begin{tabular}{lll}
\hline VolUME 73 & MAY 1964 & NUMBer 6 \\
\hline
\end{tabular}

\author{
ROBERT A. BuRT \\ JoHN A. KoskINEN \\ Elliotot J. Werss \\ WILLIAMI C. WhitFoRd \\ Note \& Comment \\ Editors
}

Jonathan A. Ater

EDWARD L. BarLOW

RIChard J. Braemser

DENNIS K. BROMIEYY

Michaer A. Brush

Donald C. Christ

Joseph D. Clayton

Edward R. CoHen

Charles J. Donahue, Jr.

ROGER D. FELDMIAN

StepHEN R. Field

Thomas $\mathrm{K}$. GrLhool.

SHERWIN M. GoldMan

JAMIES S. GORDON

\section{Peter L. Strauss \\ Editor-in-Chief \\ Monroe E. PrICE \\ Executive Editor}

\author{
Robert E. COOPER \\ STEven M. UMIN \\ Article \& Book \\ Review Editors
}

Roger W. TOMPKINS

Managing Editor

John GrIfFiths

Paul Grossman

Michael F. Halloran

Charles R. Halpern

JoHN D. Hoframan

Michael J. Horowitz

Alan D. Jacobson

Howard J. KasLow

RICHARD A. KatzIVE

JoHN L. KRAFT

Martin D. KraLI

Martin E. Lowy

Rod MCMAHAN
JosEpH D. MANDEL

Daniel Marcus

LEONARD M. MARKS

Anita S. Martin

Charles M. Nathan

Barbara H. Paul.

Edward A. Perell

David A. Ramir

Owen J. Sloane

Grorge P. Smith

WiLLARD B. TAYLOR

Allan A. Tuttle

Michael A. VARET

JOHN A. Young

EARL W. Shapiro

Business Manager

\section{CONTRIBUTORS TO THIS ISSUE}

Richard W. Jennings. A.B. 1927, Park College; A.M. 1934, University of Pennsylvania; LL.B. 1939, University of California, Berkeley.

David W. Louisell. B.S.L. 1935; LL.B. 1938, University of Minnesota.

Thomas K. Gilmooz. B.A. 1961, Lehigh University; LL.B. 1964, Yale University. 